[Transaction ]

\title{
Research on the Wearing Condition of Functional Mountaineering Garments
}

\author{
Ah-Lam Lee $\cdot$ Jeong-Rim Jeong $\cdot$ Hee-Eun Kim* ${ }^{\dagger}$ \\ Dept. of Clothing \& Textiles, Kyungpook National University \\ *Dept. of Clothing \& Textiles, Kyungpook National University/ \\ Center for Beautiful Aging, Kyungpook National University
}

Received October 7, 2009; Revised November 23, 2009; Accepted December 7, 2009

\author{
기능성 등산복의 착용실태 조사 \\ 이아람 · 정정림 · 김희은*† \\ 경북대학교 의류학과, *경북대학교 의류학과/장수생활과학연구소 \\ 접수일(2009년 10월 7일), 수정일(2009년 11월 23일), 게재확정일(2009년 12월 7일)
}

\begin{abstract}
This study investigates the actual wearing conditions of functional mountaineering garments in Korea and provides suggestions on the development of more effective functional mountaineering garments through the examination of consumer data. This survey was based on 107 respondents who enjoy mountaineering and was composed of 5 sections consisting of personal information, purchasing habits, essential features for mountaineering garments, satisfaction levels based on features and functions, and additional comments on the improvement of mountaineering garments. Respondents said that essential features for mountaineering garments are quick absorbing/drying, insulation, water and wind proof, and elasticity. These properties become more effective when users wear mountaineering garments in layers. They want lower prices and easy to wash garments. Therefore, it is necessary to consider not only the main functions, but also the needs of consumers for easy washing and price.
\end{abstract}

Key words: Outdoor garments, Wearing condition, Mountaineering garments; 아웃도어웨어, 착용실태, 등산복

\section{Introduction}

Lately, more and more people are getting interested in sports, as they invest their time in outdoor activities. Various types of outdoor activities, such as

Corresponding author

E-mail: hekim@knu.ac.kr

This work was supported by the Korea Research Foundation Grant funded by the Korea Government (MOEHRD, Basic Research Promotion Fund) (KRF-2008-313C00996). snowboarding and golf, have led to the development of new types of personal clothing described as "outdoor garments". In particular mountaineering is one of the favored outdoor activities by people in Korea, which is very mountainous. Since mountaineering is good for improvement of strength, endurance, balance and flexibility it has risen in popularity. As mountain environments have become more accessible, consumers who wear functional mountaineering garments have increased (Kariel \& Draper, 1992). Consumers are quick to discover the advantages and 
comfort of functional garments also for use in every day life ("Outdoor sportswear", 2008).

While mountaineering and other outdoor activities, people are exposed to a lot of different environments. For instance, wearers are being overdressed or underdressed, particularly when the weather changes rapidly. This phenomenon could raise the mortality since change of temperature is very dangerous in the mountains. Therefore, it is very important to wear functional mountaineering garments which are designed to protect hikers from the elements. Functional mountaineering garments will not only be correct clothing ensuring that people are comfortable and can enjoy their activity in a carefree manner, but also save wearers lives in extreme conditions.

Functional outdoor garments require four different characteristics: protection, insulation, vapor permeability and elasticity (Rupp, 1998). These are the very essential functions of outdoor garments and more technical functions are added onto extreme outdoor garments. As these functions became important, many studies about function of outdoor garments and its wearing conditions progressed. While, there is research on the wearing conditions of snowboard wear (Kim, 2006; Ryu \& Park, 2003), golf wear (Shin \& Lee, 2001) and bicycle apparel (Choi, 1999), mountaineering garments which is the most popular with consumer hasn't been studied yet.

Therefore, the main purposes of the current study were to investigate the actual condition of wearing functional mountaineering garments in Korea, and provide suggestions on development of more effective functional mountaineering garments by examining data from consumers.

\section{Methods}

This research was conducted using a questionnaire between March and May, 2008 in Daegu. The respondents of the questionnaires consisted of 56 men and 51 women who said they enjoy mountaineering.

The questionnaire constituted 5 section - personal information, purchasing habit, essential features for mountaineering garments, satisfaction levels based on features and functions, and additional comments on the improvement of mountaineering garments (Table 1). Four questions on personal information included gender, age, experience in mountaineering and motivation for mountaineering. There were 2 questions on purchasing habit, purchasing price and interest of apparel brand. The section about essential features for mountaineering garments consisted of 10 questions about apparel issues; quick absorbing/drying, water and wind proof, insulation, antibiosis/deodorization, UV protection, antistatic, cool touch, elasticity, lightweight, and durability. These questions covered four kinds of garments respectively. The satisfaction section consisted of 15 questions which asked about

Table 1. Constitution of questionnaires

\begin{tabular}{l}
\hline \hline Personal information \\
\hline Gender \\
Age \\
Experience in mountain climbing \\
Motivation of mountaineering \\
\hline Purchasing habit \\
\hline Purchasing price \\
Interest of apparel brand \\
\hline Essential features for mountaineering garments \\
\hline Quick absorbing/drying \\
Water and wind proof \\
Insulation \\
Antibiosis/deodorization \\
UV protection \\
Antistatic \\
Cool touch \\
Elasticity \\
Lightweight \\
Durability \\
\hline Satisfaction levels based on features and functions \\
\hline Quick absorbing/drying \\
Water and wind proof \\
Insulation \\
Antibiosis/deodorization \\
UV protection \\
Antistatic \\
Cool touch \\
Elasticity \\
Lightweight \\
Durability \\
Sewing quality \\
Easy care \\
Multiplicity of size \\
\hline
\end{tabular}


sewing quality, laundry/management, multiplicity of size, suitable fitting, Shaping the body, as well as 10 questions which mentioned the essential features for mountaineering garments. The questions from the satisfaction section were measured with the 5-point Likert Scale (1-very dissatisfied, 2-dissatisfied, 3-neither satisfied nor dissatisfied, 4-satisfied, 5-very satisfied). Finally, additional comments on the improvement of mountaineering garments were collected. The data gathered from the survey was analyzed by frequencies, percentiles, average and standard deviation.

\section{Results and Discussion}

The respondents of the questionnaire consisted of 107 persons (56 males and 51 females, age $42.4 \pm 11.8$ years) who claimed they enjoyed mountaineering. There were 65 respondents $(60 \%)$ who have had more than five years of experience in mountaineering, and 58 persons $(54.2 \%)$ answered that their motivation for mountaineering was to improve health. This fact is attributable to the growing interest in health due to the Well Being trend and more time allowed for leisure activities because of the implementation of the five day workweek system (Ko \& Lee, 2001). Therefore, mountaineering garments which can help management of their health.

As the price is concerned, the higher the price the less people purchased all garments items such as outerwear, shirts, and pants. In general, consumers tended to regard high priced garments as being more qualified. However, excessively over priced garments made them lose interest in buying and forced them to pursue lower price alternatives (Lee \& Lim, 2000). In the preference of apparel brand, the respondents had interest in both domestic and international brands. Jin and Rhee (2007) reported that the consumers who have more knowledge in apparel products tend to show interest in fabric brands more than in apparel brands. When new functional fabric is developed, it is launched in the name a fabric brand in apparel markets. Fabric brand takes priority for consumers in choosing the right functional garments. Therefore, consumers who have no knowledge of functional fabric can't consider the feature of fabric.

<Fig. 1> shows cumulative frequency of essential features for mountaineering garments. essential features, which they choose across all garments items, were quick absorbing/drying, insulation, water and wind proof, elasticity, light weight, and so on. Especially in shirts and underwear, the preferred properties were quick absorbing/drying and insulation. Sweating decreases the body temperature due to heat evaporation. However, if a large amount of sweat remains at the surface of the apparel or body then heat is not removed effectively and fabric clings to

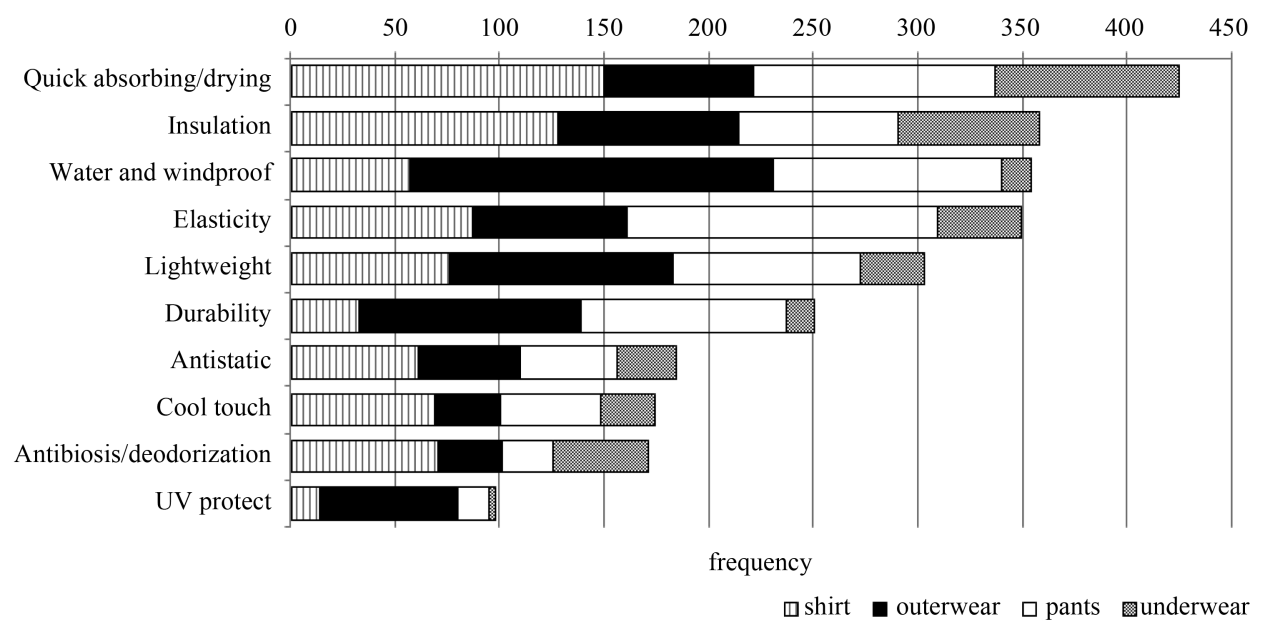

Fig. 1. Cumulative frequency of essential features for mountaineering garments. 
skin causing discomfort (Okubo et al., 2008). In order to keep the wearer's body dry, fabrics for mountaineering garments should have the capability to wick moisture away from skin, distribute it over the fabric surface, and reduce drying times. Chaudhari et al. (2007) noted that the main parameters for comfort and functionality were water/wind proof, breathability/ comfort, moisture/sweat management, warmth/temperature control, easy-care performance, and smart/functional design. Moisture handling properties of fabric during intense physical activities has been regarded as a major factor in comfort performance.

Respondents answered that water and wind proof properties are important features of outerwear. Water and wind proof fabric completely prevents the absorption of liquid water and penetration of wind. Havenith (2002) said that air movement can disturb the air layers in ensemble, by entering through clothing openings or by penetration of the clothing fabric which is depending on the air permeability of the outer clothing layer. Since the weather in mountains changes rather quickly, outwear should be water and wind proof material such as high-density, resin-coated and film-laminate fabrics to protect the body from the outer environment (Wong \& Li, 2004).

Quick absorbing/drying, insulation, and water and wind proof properties become more effective when donning mountaineering garments using a layering system. We suppose that climbers could maintain a comfortable body temperature during and after exercise, no matter what the weather is like. The layering system consists of three basic layers which are the outer layer, mid layer and base layer. The outer layer protects climbers from wind, rain and snow. The mid layer provides insulation and keeps them warm, while the base layer provides insulation and wicks sweat away from skin. The layering system is very flexible with hot and cold. However, clothing use in this layering system should be lightweight ("The Layering System", 2008). The fact that weight of clothing is critical to the layering system corresponds with the responses from this survey.

In case of pants, property of elasticity was the most essential characteristic. Mountaineering, in particular uphill walking, demands a higher level of stretch performance, in comparison to on level trails (Burtscher, 2004). There is a lot of movement and extension of the skin surface at lower limbs, the stretch fabric could supplement the extension of skin surface (Cho, 2004).

Satisfaction levels based on features and functions is represented in <Table 2>. Their satisfactory level

Table 2. Satisfaction levels based on features and functions $(\mathrm{n}=107, \mathrm{n}(\%))$

\begin{tabular}{l|c|c|c|c|c|c}
\hline \hline & $\begin{array}{c}\text { very } \\
\text { dissatisfied }\end{array}$ & dissatisfied & $\begin{array}{c}\text { neither satisfied } \\
\text { nor dissatisfied }\end{array}$ & satisfied & $\begin{array}{c}\text { very } \\
\text { satisfied }\end{array}$ & $\begin{array}{c}\text { no } \\
\text { answer }\end{array}$ \\
\hline Quick absorbing/drying & $6(5.6)$ & $3(2.8)$ & $35(32.7)$ & $41(38.3)$ & $16(15.0)$ & $6(5.6)$ \\
\hline Water and wind proof & $6(5.6)$ & $7(6.5)$ & $17(15.9)$ & $46(43.0)$ & $26(24.3)$ & $5(4.7)$ \\
\hline Insulation & $5(4.7)$ & $6(5.6)$ & $28(26.2)$ & $46(43.0)$ & $17(15.9)$ & $4(3.7)$ \\
\hline Antibiosis/deodorization & $7(6.5)$ & $21(19.6)$ & $40(37.4)$ & $19(17.8)$ & $5(4.7)$ & $15(14.0)$ \\
\hline UV protection & $4(3.7)$ & $21(19.6)$ & $39(36.4)$ & $18(16.8)$ & $6(5.6)$ & $19(17.8)$ \\
\hline Antistatic & $5(4.7)$ & $18(16.8)$ & $28(26.2)$ & $34(31.8)$ & $7(6.5)$ & $15(14.0)$ \\
\hline Cool touch & $6(5.6)$ & $6(5.6)$ & $37(34.6)$ & $35(32.7)$ & $11(10.3)$ & $12(11.2)$ \\
\hline Elasticity & $5(4.7)$ & $5(4.7)$ & $21(19.6)$ & $49(45.8)$ & $19(17.8)$ & $8(7.5)$ \\
\hline Lightweight & $4(3.7)$ & $4(3.7)$ & $22(20.6)$ & $46(43.0)$ & $21(19.6)$ & $10(9.3)$ \\
\hline Durability & $4(3.7)$ & $12(11.2)$ & $24(22.4)$ & $41(38.3)$ & $16(15.0)$ & $10(9.3)$ \\
\hline Sewing quality & $3(2.8)$ & $3(2.8)$ & $25(23.4)$ & $55(51.4)$ & $16(15.0)$ & $5(4.7)$ \\
\hline Easy care & $9(8.4)$ & $16(15.0)$ & $33(30.8)$ & $36(33.6)$ & $7(6.5)$ & $6(5.6)$ \\
\hline Multiplicity of size & $4(3.7)$ & $8(7.5)$ & $37(34.6)$ & $45(42.1)$ & $8(7.5)$ & $5(4.7)$ \\
\hline Suitable fitting & $4(3.7)$ & $8(7.5)$ & $39(36.4)$ & $39(36.4)$ & $10(9.3)$ & $7(6.5)$ \\
\hline Shaping the body & $9(8.4)$ & $33(30.8)$ & $31(29.0)$ & $18(16.8)$ & $5(4.7)$ & $11(10.3)$ \\
\hline
\end{tabular}


was "4-satisfied" for the most part of characteristics. In additional comments on the improvement of mountaineering garments, 54 respondents described that they wanted lower purchasing prices. The results show that consumers consider the price of garments as on of the most important factors when shopping for mountaineering garments. Eleven respondents answered that they wanted improvements in quality, 7 respondents wanted better design and 6 respondents wanted easy washing. Functional mountaineering garments can be washed with water but they misunderstood that mountaineering garments should be dry-cleaned. In order to solve this washing problem, it is necessary for the sales person to give a brief explanation of how to wash, or use a clear launder symbols on a tag to clients. Other than that, various colors and easy to understand product descriptions were needed, while misleading advertisements should be avoided.

\section{Conclusions}

This study reported the results from a survey study on wearing condition of functional mountaineering garments. We found that quick absorbing/drying, insulation, and water and wind proof functions were the essential features for mountaineering garments. These features help maintaining the body temperature and protect wearer's body from environmental hazard. We also figure out that elasticity was the essential feature in pants for easy movement of lover limbs. Consumers wanted more improved function of garments with lower prices. Therefore, it is necessary to develop mountaineering garment with considering not only functions but also consumers' needs, such as the lower price. This study could be applied to plan the development and marketing strategy for the functional mountaineering garment.

\section{References}

Burtscher, M. (2004). Exercise capacity of mountaineering: How much is necessary? Research in Sports Medicine, 12, 242-250.

Chaudhari, S. S., Chitnis, R. S., \& Ramkrishnan, R. (2007, November 20). The Synthetic and Art Silk Mills' Re- search Association. Sasmira. Retrieved March 2, 2009, from http://www.sasmira.org/publication.htm

Cho, S. H. (2004). Changes in body surface lines caused by lower limb movements in designing slacks (I). Korean J. of Human Ecology, 7(3), 15-33.

Choi, M. S. (1999). The preferred style of bicycle apparel in Korea and the United States. J. of the Korean Society, 23(5), 684-693.

Havenith, G. (2002). Interaction of clothing and thermoregulation. Exog. Dermatol., 1(5), 221-230.

Jin, H. J., \& Rhee, E. Y. (2007). Product evaluations toward apparel brand and ingredient brand related to outdoor sportswear consumers' leisure involvement and product knowledge. J. of Korean Society of Clothing and Textiles, 31(9/10), 1333-1341.

Kariel, H. G., \& Draper, D. L. (1992). Outdoor recreation in mountains. Geo J., 27(1), 97-104.

Kim, S. B. (2006). A study of purchasing traits and the wearing satisfaction of ski wear. J. of the Korea Society for Clothing Industry, 8(3), 293-302.

Ko, S. H., \& Lee, J. Y. (2001). Cluster analysis according to physical leisure activities with social psychological characteristics factor. The Korean J. of Physical Education, 40(3), 93-106.

Lee, H. S., \& Lim, S. J. (2000). The effect of price and brand on the perceived quality, value and purchase of clothing. J. of the Korean Society of Clothing and Textiles, 24(4), 498-509.

Okubo, M., Saeki, N., \& Yamamoto, T. (2008). Development of functional sportswear for controlling moisture and odor prepared by atmospheric pressure nonthermal plasma graft polymerization induced by RF glow discharge. J. of Electrostatics, 66, 381-387.

Outdoor sportswear. (2008). Fashion Infomat. Retrieved March 2, 2009, from http://www.infomat.com/research/ infre0000367.html

Rupp, J. (1998). Functional sportswear. Int. Tex. Bull, 44(4), $14-20$.

Ryu, S. A., \& Park, K. S. (2003). Research on the actual condition of snowboard wear. The Research $J$. of the Costume Culture, 11(5), 721-736.

Shin, S. M., \& Lee, J. R. (2001). Consumers' preference and dissatisfaction on knitted golf wear. J. of the Korean Society of costume, 51(4), 97-112.

The Layering System. (2008). Outdoor clothing advice. Retrieved March 2, 2009, from http://www.cheaptents. com/Advice-clothing.htm

Wong, A. S. W., \& Li, Y. (2004). Relationship between thermophysiological responses and psychological thermal perception during exercise wearing aerobic wear. $J$. Therm. Biol., 29, 791-796. 


\section{요 약}

본 연구는 기능성 등산복의 착용실태를 조사하여 등산복의 개발과 차별화에 기여하고자 하였다. 등산 을 즐기는 107 명의 응답자들이 본 설문조사에 응해주었고 문항은 개인정보, 구매습관, 등산복 선택시 가 장 중요하게 여기는 기능, 본인이 소유한 등산복의 기능에 대한 만족도, 자유기술의 5 개 항목으로 이루어 져 있었다. 응답자들은 기능성 등산복을 선택할 때에 가장 중요하게 여기는 특성으로 흡습속건성, 보온성, 방수방풍성, 스트레치성 기능을 열거하였다. 이 기능들은 한 겹의 의복으로 착용하기보다는 여러 겹 겹쳐 입을 경우 특히 그 효과가 증대한다 할 수 있다. 그리고 스트레치성의 경우 하체의 움직임이 많은 등산 활 동 시 하의에 특히 필요한 기능이라 응답하였다. 그리고 응답자들은 기능성 등산복의 가격이 너무 비싸다 고 응답하였으며 세탁이 불편하다고 답하였다. 이러한 설문결과로 보아 기능성 등산복의 개발 시 소비자 들이 중요하게 여기는 기능을 고려해야 할 뿐만 아니라, 세탁성이나 가격과 같은 소비자들이 개선을 원하 는 요소들에 대한 고려도 필요할 것이다. 